\title{
SUPERIOR RESPONSIBILITY UNDER THE ROME STATUTE AND ITS APPLICABILITY TO CONSTITUTIONAL MONARCHY: AN APPRAISAL*
}

\author{
Abdul Ghafur Hamid** \\ Mohd Hisham Mohd Kamal ${ }^{* * *}$ \\ Muhannad Munir Lallmahamood*** \\ Areej Torla****
}

\begin{abstract}
The doctrine of superior responsibility has been embedded in Article 28 of the Rome Statute of the International Criminal Court, which enunciates the responsibility of both military commanders and civilian superiors. Although constitutional monarchs are civilians entrusted with the position of commanders in chief, there are States that opposed accession to the Rome Statute on the simple ground that their respective monarchs could be indicted and punished under the Rome Statute. The main objective of this paper, therefore, is to examine whether constitutional monarchs could be responsible under the doctrine of superior responsibility. The paper focuses on the analysis of the elements of superior responsibility by referring to the authoritative commentaries of Article 28 and constitutional practices of three selected constitutional monarchies: the United Kingdom, Japan and
\end{abstract}

This paper is funded by a Fundamental Research Grant Scheme (FRGS), granted by the Ministry of Education of Malaysia under the Project ID: FRGS19-132-0741.

** Professor and Coordinator of the International Law and Maritime Affairs (ILMA) Research Unit, Ahmad Ibrahim Kulliyyah of Laws, International Islamic University Malaysia; email: ghafur@iium.edu.my.

*** Associate Professor, Ahmad Ibrahim Kulliyyah of Laws, International Islamic University Malaysia; email mkmhisham@iium.edu.my.

${ }^{* * * *}$ LL.B. (Hons), Final Year Student, Ahmad Ibrahim Kulliyyah of Laws, International Islamic University Malaysia; email: muhannadmunir@gmail.com.

***** Assistant Professor, Civil Law Department, Ahmad Ibrahim Kulliyyah of Laws, International Islamic University Malaysia. Email: areej@iium.edu.my. 
Malaysia. The paper finds that constitutional monarchs could not be held responsible because they have to act on the advice of the government and do not possess the effective and operational control over the armed forces as required under the Rome statute.

Keywords: $\quad$ Superior responsibility, command responsibility, Rome Statute, Constitutional monarchy.

\section{TANGGUNGJAWAB ATASAN BAWAH STATUT ROM DAN KEBOLEHPAKAIAN PADA RAJA BERPELEMBAGAAN: SUATU PENILAIAN}

\section{ABSTRAK}

Doktrin tanggungjawab atasan telah termaktub dalam Perkara 28 Statut Rom Mahkamah Jenayah Antarabangsa, yang menyatakan tanggungjawab komander tentera dan orang atasan awam. Walaupun raja-raja berperlembagaan adalah orang awam yang diamanahkan dengan jawatan ketua komander, terdapat negara yang membantah kesertaan ke dalam Statut Rom atas alasan mudah bahawa raja masingmasing boleh didakwa dan dihukum di bawah Statut Rom. Oleh itu, objektif utama makalah ini adalah untuk meneliti samaada raja berperlembagaan boleh dipertanggungjawabkan di bawah doktrin ini. Makalah ini memberi tumpuan kepada analisis unsur tanggungjawab atasan dengan merujuk kepada ulasan berwibawa tentang Perkara 28 dan amalan perlembagaan tiga negara raja berperlembagaan terpilih: United Kingdom, Jepun, dan Malaysia. Makalah ini mendapati bahawa raja berperlembagaan tidak boleh dipertanggungjawabkan kerana mereka perlu bertindak atas nasihat kerajaan dan tidak memiliki kawalan yang efektif dan operasional ke atas angkatan tentera seperti yang dikehendaki di bawah Statut Rom.

Kata kunci: Tanggungjawab atasan, tanggungjawab perintah, Statut Rom, negara raja berperlembagaan.

\section{INTRODUCTION}

World War II was the impetus that led to the creation of a doctrine, which gives rise to the notion that military commanders and civilian leaders would be criminally responsible when they have failed to prevent or punish the international crimes committed by their 
subordinates. ${ }^{1}$ This doctrine of "superior responsibility" 2 is a kind of liability for superiors resulting from a lack of supervision over their subordinates who commit international crimes. ${ }^{3}$

The doctrine is enshrined in Article 28 of the Rome Statute of the International Criminal Court (ICC). ${ }^{4}$ An interesting question is whether the monarchs in constitutional monarchies, who are also entrusted with the position of commanders-in-chief, could be guilty of superior responsibility. Some constitutional monarchs already have adopted the Rome Statute, without having much concern about this issue.

However, in a constitutional monarchy such as Malaysia, there have been strong and dedicated objections against the accession to the Rome Statute for the simple reason that their monarchs should not be subject to trial under this doctrine.

1 Guenael Mettraux, "The Evolution of the Law of Command Responsibility and the Principle of Legality," in The Law of Command Responsibility (Oxford: Oxford University Press, 2009), 5.

2 From the very outset, it is necessary to comment on the use of the term "superior responsibility." Traditionally, the doctrine has been known as "command responsibility" as it is mainly concerned with military commanders. However, with time, the doctrine has evolved to include non-military (civilian) superiors as well. While many commentators still address the doctrine as 'command responsibility,' many others prefer to address it as "superior responsibility," arguing that commanders are also superiors, and the term superior encompasses both "military commanders and civilian superiors." See Rene Vark, "Superior Responsibility", ENDC Proceedings, 15 (2012): 143-161, at 144; see also Kai Ambos, "Superior Responsibility," in Antonio Cassese, Paola Gaeta and John R.W.D. Jones (eds) The Rome Statute of the International Criminal Court: A Commentary (Oxford: Oxford University Press, 2002) [hereinafter "Kai Ambos "Superior responsibility" in Rome Statute Commentary"], 806.

3 Jerome de Hemptinne, Robert Roth and Elies van Sliedregt, "Command Responsibility," in Modes of Liability in International Criminal law (Cambridge: Cambridge University Press, 2019), 410; Kai Ambos "Superior Responsibility," in Rome Statute Commentary, 806.

4 The Rome Statute of the International Criminal Court, adopted at Rome on 17 July 1998, entered into force on 1 July 2002, 2187 UNTS 3 [hereinafter "Rome Statute"]. 
Malaysia deposited its instrument of accession to the Rome Statute on 4 March 2019. ${ }^{5}$ However, Malaysia's adopting of the Rome Statute ignited uproar throughout the country. Opposition parties and interest groups, with the support of certain royalties, vehemently moved against the accession. The Johor crown prince Tunku Ismail Ibrahim, for example, argued that

Signing the Rome Statute would risk putting the Yang di-Pertuan Agong (YDPA) i.e., the constitutional monarch in Malaysia in a precarious position of being liable and being dragged to the ICC. ${ }^{6}$

The same objection was raised by the then Opposition leader Ismail Sabri Yaakob. ${ }^{7}$

In a political twist, four academics from Malaysian public universities presented a paper entitled "Rome Statute and Malaysia" to the Conference of Rulers. There was widespread criticism to the effect that

the arguments in the paper were very biased as they only discussed why the Conference of Rulers should reject the Rome Statute. Some commentators have alleged that the academics were the real cause of the confusion. ${ }^{8}$

As a result of this, there were public protests and demonstrations against the Rome Statute. The Government finally

5 "Malaysia Accedes to the Rome Statute of the International Criminal Court," Press Release, Ministry of Foreign Affairs: Wisma Putra, Putra Jaya, 4 March 2019.

6 Ida Lim, "Rome Statute : What is it? Will Agong's immunity be at risk?" Malay Mail, March 25 2019, accessed July 12, 2021,https://www.malaymail.com/news/malaysia/2019/03/25/romestatute-what-is-it-will-agongs-immunity-be-at-risk/1736067.

7 "Malaysia withdraws from the Rome Statute of the International Criminal Court?" The Straits Time, May 4, 2019, accessed July 12, 2021, https://www.straitstimes.com/asia/se-asia/malaysia-withdrawsfrom-the-rome-statute.

8 Jia Vern Tham, "Conference of Rulers Rejected the Rome Statute Based on a Biased Paper," SAYS, 8 April 2019, https://says.com/my/news/thepaper-which-allegedly-convinced-conference-of-rulers-to-reject-therome-statute, accessed August 16, 202; Lim Wei Jiet, "A Rebuttal of the Alleged Academic Presentation to Rulers," Malaysiakini, 8 November 2019, https://www.malaysiakini.com/news/471305, accessed August 15, 2021. 
decided to withdraw from the Rome Statute on 5 April 2019. ${ }^{9}$ Since this is a very unfortunate situation, it is of utmost importance to set the record right.

The main objective of this paper, therefore, is to explore whether constitutional monarchs, like the YDPA in Malaysia, who are also the commanders-in-chief of the armed forces, would be responsible for the international crimes committed by their subordinates under the doctrine of superior responsibility embedded in Article 28 of the Rome Statute. This paper focuses on three aspects. Firstly, the interpretation of Article 28(a) and (b) of the Rome Statute and the analysis of the elements of superior responsibility by referring to the authoritative commentaries and cases decided by the International Criminal Tribunal for the Former Yugoslavia (ICTY), the International Criminal Tribunal for Rwanda (ICTR) and the International Criminal Court (ICC). Secondly, the paper investigates the power of constitutional monarchs as the commanders-in-chief in selected countries in the actual operation and chain of command of the armed forces based on their constitutional law and practices. Thirdly, the paper applies the elements of superior responsibility under the Rome Statute to the situation of constitutional monarchs in selected countries and tries to reach a conclusion on whether they could be held responsible under the Rome Statute.

\section{ELEMENTS OF SUPERIOR RESPONSIBILITY UNDER THE ROME STATUTE}

The most recent codification of superior responsibility can be found in Article 28 of the Rome Statute. ${ }^{10}$ Under superior responsibility, a

9 "Malaysia Withdraws from the Rome Statute," The Star Online, 5 April 2019, https://www.thestar.com.my/news/nation/2019/04/05/malaysiawithdraws-from-the-rome-statute, accessed July 12, 2021; See also "KL's Rome Statute U-Turn A Move to Prevent Coup - Minister," The Straits Times, 8 April 2019, https://www.straitstimes.com/asia/seasia/kls-rome-statute-u-turn-a-move-to-prevent-coup-minister, accessed July 12, 2021, 2019.

10 Rome Statute, Article 28. 
superior is punished for failure to act. ${ }^{11}$ The accused is not charged with the crimes of the subordinate but for failure to exercise effective control over his subordinates. ${ }^{12}$

As a result of extensive negotiations, it was agreed in the Rome Conference to set separate conditions for military commanders on one hand and civilian superiors on the other. ${ }^{13}$ Therefore the Article enunciates two slightly different superior responsibility standards: one for military commanders and another for civilian superiors.

\section{Elements of Supreme Responsibility for a Military Commander} Elements of Supreme Responsibility for military commanders are enunciated in Article 28(a) and decided cases.

The Pre-Trial Chamber of the ICC in Bemba's case held:

"In order to prove criminal responsibility within the meaning of Article 28(a) of the Statute, the following elements must be fulfilled:

(i) The suspect must be either a military commander or a person effectively acting as a military commander (superiorsubordinate relationship);

(ii) The suspect must have effective command and control, or effective authority and control over the forces who committed crimes set out in the Statute (effective command/authority and control);

(iii) The crimes committed by the forces resulted from the suspect's failure to exercise control properly over them (causation);

(iv) The suspect either knew or, owing to the circumstances at the time, should have known that the forces were committing or about to commit such crimes (mens rea: mental element; knowledge of the crime); and

11 Elies van Sliedregt, "Article 28 of the ICC Statute : Mode of Liability and/or Separate Offense ?" New Criminal Law Review: An International and Interdisciplinary Journal 12, no. 3 (2009): 422.

12 Krnojelac case, Prosecutor v. Milorad Krnojelac, Appeals Chamber, IT97-25-A, 17 September 2003, ICTY, para. 171.

13 Rene Vark, 148. 
(v) The suspect failed to take the necessary and reasonable measures within his or her power to prevent or repress the commission of such crimes or failed to submit the matter to the competent authorities for investigation and prosecution (superior's failure to prevent, repress, or punish the crime)." 14

\section{Elements of Supreme Responsibility for a Civilian Superior}

Elements of Supreme Responsibility for civilian superiors are enunciated in Article 28(b) and decided cases.

A comparison between Article 28(a) and 28(b) of the Rome Statute clearly demonstrates the fact that there are indeed differences between the elements of responsibility for military commanders and those for civilian superiors. All the five elements for military commanders are also applicable to civilian superiors. However, the following are the differences:

(i) As far as the fourth element (mental element) is concerned there is a slight modification in the case of civilian superiors ("should have known" is replaced by "consciously disregarded information." $)^{15}$

(ii) There is an extra element (the sixth element) for civilian superiors that " $[t]$ he crimes concerned activities that were within the effective responsibility and control of the superior." 16

There are altogether six elements for a civilian superior to be responsible under the Rome Statute. These will be analysed one after another in the following section.

14 Bemba's case, Prosecutor v Jean-Pierre BembaGombo, Pre-Trial Chamber II, Decision Pursuant to Article 61(7)(a) and (b) of the Rome Statute on the Charges of the Prosecutor Against Jean-Pierre Bemba Gombo, Case No. ICC-01/05-01/08-424, 15 June 2009, para. 407; [hereinafter referred to as "Bemba's case"].

15 Rome Statute, Article 28(b)(i).

16 Ibid., Article 28(b)(ii). 


\section{First Element: Superior-Subordinate Relationship}

The Rome Statute makes a clear bifurcation between the responsibility of military commanders or persons acting as military commanders and that of civilian superiors.

\section{A military commander or person effectively acting as a military commander}

In Bemba's case, the Trial Chamber defines military commander as:

A category of persons who are formally or legally appointed to carry out a military commanding function (i.e., de jure commanders). The concept embodies all persons who have command responsibility within the armed forces, irrespective of their rank or level. In this respect, a military commander could be a person occupying the highest level in the chain of command or a mere leader with few soldiers under his or her command. The notion of a military commander under this provision also captures those situations where the superior does not exclusively perform a military function. ${ }^{17}$

Bemba's case again defines a person effectively acting as a military commander to cover de facto commanders:

This category refers to those who are not elected by law to carry out a military commander's role, yet they perform it de facto by exercising effective control over a group of persons through a chain of command. This would include superiors who have authority and control over regular government forces such as armed police units or irregular forces (non-government forces) such as rebel groups, paramilitary units including, inter alia, armed resistance movements and militias that follow a structure of military hierarchy or a chain of command. ${ }^{18}$

\section{A Civilian superior}

Article 28(b) of the Rome Statute deals with "superiors who are not military commanders or effectively acting as military commanders." 19

\footnotetext{
17 Ibid., para. 408.

18 Ibid., para. 409-410.

19 Rome Statute, Article 28(b).
} 
The applicability of superior responsibility to civilian superiors can be seen in the jurisprudence of both the ICTY and the ICTR.

The ICTR decided in Akayesu's case that superior responsibility applies to non-military superiors as well. This was on the basis that during the Tokyo trials, the former Japanese foreign minister (non-military superior) was convicted for war crimes (mass rape) under the doctrine of superior responsibility. ${ }^{20}$

In the case of Kayishema and Ruzindana, the ICTR held that

the doctrine of superior responsibility extends to political leaders and other civilian superiors in positions of authority. ${ }^{21}$

In Musema's case, the accused was the Director of the Gisovu Tea Factory in the Kibuye Prefecture in Rwanda. He was therefore a civilian superior. As Director of the factory, he exercised effective control over his employees, who

perceived him as a figure of authority and as someone who wielded considerable power in the region.

Although he was able to take reasonable measures to prevent the crimes, he did nothing and took no steps to punish the perpetrators over whom he had control. He was held liable for the crimes committed by the employees of the Gisovu Tea Factory. ${ }^{22}$

In Kambanda's case, Jean Kambanda was the former Prime Minister of Rwanda. As the Prime Minister, he exercised de jure and de facto authority and control over his government ministers, the military, and powerful local authorities. Before the ICTR, he pleaded guilty to genocide and crimes against humanity for his own acts as well as under superior responsibility. ${ }^{23}$

In Serushago's case, Omar Serushago, a local civilian leader, had effective authority and control over local militiamen. Before the

20 Akayesu's case (Prosecutor v. Jean-Paul Akayesu) Trial Chamber I, ICTR-96-04-T, 2 September 1998, ICTR, para. 490.

21 Kayishema and Ruzindana's case (Prosecutor v. Clêment Kayishema and ObedRuzindana) Trial Chamber II, ICTR-95-1-T, 21 May 1999, ICTR, paras. 214-215 [hereinafter referred to as Kayishema's case].

22 Musema's case (Prosecutor v Alfred Musema), Trial Chamber I, ICTR96-13-A, Judgment of 27 January 2000, ICTR, paras. 999-1004.

23 Kambanda's case (Prosecutor v Jean Kambanda), Trial Chamber I, ICTR-97-23-S, Decision of 4 September 1998, paras 5-7. 
ICTR, he pleaded guilty to genocide and crimes against humanity for his own acts as well as under superior responsibility. ${ }^{24}$

In the case of Bagilishema, the Prosecutor argued that the Trial Chamber erred when it held that civilians could only be found to be liable under command responsibility if they exercise a military command authority. The Appeal Chamber held that:

The Trial Chamber's approach of effective control in relation to civilian superiors is erroneous in law because as long as a superior has effective control over the subordinates, to the extent that he can prevent them from committing the crimes or punishing them after they committed the crimes, he would be held responsible under superior responsibility for his failure to act. ${ }^{25}$

\section{Second Element: Effective command/authority and control}

Article 28 of the Rome Statute provides that

a superior will be criminally responsible for crimes committed by forces under his or her effective command and control or effective authority and control. ${ }^{26}$

Effective control can be defined as "the material ability [or power] to prevent and punish the commission of offences." 27 Then how can effective control be determined? It is a question of fact determinable under the circumstances of each case and there are several factors that elucidate whether the accused possessed the material ability to prevent and punish the commission of offences. ${ }^{28}$ These factors have been listed in Bemba's case as follows:

[T] he official position of the suspect; his power to issue or give orders and the capacity to ensure compliance with the orders

24 Serushago's case (Prosecutor v Omar Serushago), Trial Chamber I, ICTR-98-39-S, Decision of 5 February 1999, para. 3.

25 Bagilishema's case (Prosecutor v. Ignace Bagilishema) Appeals Chamber, ICTR-95-1A-A, 3 July 2002, ICTR, para. 49-50.

26 Rome Statute, Article 28.

27 Bemba's case, para. 415; Čelebići's Appeal case (Prosecutor v. Mucić et al.) Appeals Chamber, IT-96-21-A, 20 February 2001, ICTY, para. 256.

28 Bemba's case, para. 416 ; Blaskić's case (Appeals Chamber)(Prosecutor v TihomiBlaskić), ICTY, IT-95-14-A, Judgment of 29 July 2004, ICTY Appeals Chamber, para. 69. 
issued; his position within the military structure and the actual tasks that he carried out; the capacity to order forces or units under his command to engage in hostilities; the power to promote, replace, remove or discipline any member of the forces; and the authority to send forces where hostilities take place and withdraw them at any given moment. ${ }^{29}$

The official position of the suspect

In Bemba's case, the Pre-Trial Chamber examined Mr. Bemba's official position and found that he was the President of the 'Movement for the Liberation of Congo' (MLC). Article 12 of the MLC Statute provides that

the President of the MLC is the head of the political wing and the Commander-in-Chief of the Armée de Libération du Congo (ALC).

Mr Bemba as the President of the MLC had to determine military objectives, approve and sign defence agreements, and preside over the meetings of the ALC, the military wing of the MLC. It is Mr Bemba who had the power to appoint and dismiss the members of the General Staff of the ALC. The Chief of Staff had to execute the decisions made by Mr Bemba. Evidence was also provided to show that $\mathrm{Mr}$ Bemba appointed the brigade and battalion commanders. ${ }^{30}$

The power to appoint, promote, demote, dismiss member of the armed forces

In Bemba's case, as seen above from the MLC structure and the evidence provided, Mr Bemba had the power to not only appoint, promote, demote, and dismiss members of the MLC but also had the power to arrest, detain and release those who were arrested. ${ }^{31}$

\footnotetext{
29 Bemba's case, para. 417.

30 Ibid, para. 453-456.

31 Ibid, para. 460.
} 


\section{The power to prevent the commission of the crimes}

In Bemba's case, there was a military judicial system within the MLC structure where $\mathrm{Mr}$ Bemba could have submitted matters for investigation and prosecution. Mr Bemba issued a decree on the establishment of a court-martial in 2002. Evidence provided showed that $\mathrm{Mr}$ Bemba took disciplinary measures when certain crimes were allegedly committed by the MLC troops in $2001 .^{32}$

The power to issue orders and to ensure compliance with the orders issued

Again, in Bemba's case, evidence was provided to show that there was a reporting system, which allowed Mr Bemba to monitor the military operations of the MLC and to directly contact the commanders in order to issue orders. Evidence was also provided to show that these orders were complied with and in the event the orders were not followed, punishment ensued. ${ }^{33}$

In Karera's case, evidence was provided to show that Karera had given orders, which were followed. For instance, the policemen followed Karera's orders to kill Tutsi and destroy their houses. Karera ordered the policemen to spare the lives of Callixte and Augustin and their relatives, and that this order was followed. Furthermore, Karera ordered the policemen not to destroy certain houses and this too was followed. $^{34}$

In Blaskic's case, the Appeals Chamber ruled that

Proof is required that the accused was not only able to issue orders but that the orders were actually followed. ${ }^{35}$

In this case, there was evidence to show that the Appellant's orders were not carried out. The Appeals Chamber finally concluded that

the accused lacked effective control over the military units responsible for the commission of the crimes, in the sense of a material ability to prevent or punish criminal conduct, and

\footnotetext{
32 Bemba's case, para. 461-464.

33 Ibid, para. 459.

34 Karera's case (Prosecutor v. François Karera) Trial Chamber I, ICTR01-74-T, 7 December 2007, ICTR, para. 565.

35 Blaskić's case, para. 69.
} 
therefore the constituent elements of command responsibility have not been satisfied. ${ }^{36}$

Based on this, if there is evidence to show that orders are not being complied with, this can be an indicator to show that the superior lacked "effective control over his or her subordinates."

Thus, to determine whether the accused had effective control, each of the factors must be analysed in any given case and case law illustrates that greater weight is given to the factor of the ability to issue orders and ensure compliance with the orders.

\section{Third Element: Causation}

Although causation appears to be an element under the Rome Statute, the issue, however, is to what extent this must be proved. The ICC has held in the Bemba'scase that

the causation element only applies to cases where a commander or superior failed to prevent crimes and in addition the failure to act by the superior must have increased the risk of the commission of the crimes. ${ }^{37}$

\section{Fourth Element: The Superior's Knowledge of the Crime (Mens Rea)}

As far as the mental element is concerned, the requirement of civilian superiors is different from that of military commanders.

The standard for military commanders is that the commander knew or should have known. ${ }^{38}$ The standard for civilian superiors is that the superior knew, or consciously disregarded information which clearly indicated, that the subordinates were committing or about to commit crimes. ${ }^{39}$

The first limb is the requirement of actual knowledge. This is the same as the requirement for military commanders. In relation to the

\footnotetext{
36 Ibid., paras. $399 \& 421$.

37 Bemba's case, para. 426. SeealsoNtaganda's case (Prosecutor v. Bosco Ntaganda) Decision Pursuant to Article 61(7)(a) and (b) of the Rome Statute on the Charges of the Prosecutor Against Bosco Ntaganda PreTrial Chamber II, ICC-01/04-02/06, 9 June 2014, ICC, para. 174.

38 Rome Statute, Article 28(a)(i).

39 Rome Statute, Article 28(b)(i).
} 
second limb, "consciously disregarding information" is similar to the "wilfully blind" criteria used in common law. ${ }^{40}$ Čelebici's case defines willful blindness as a superior simply ignoring information within his actual possession compelling the conclusion that criminal offenses are being committed or about to be committed. ${ }^{41}$ Therefore, the following requirements must be fulfilled cumulatively:

information clearly indicating a significant risk that subordinates were committing or were about to commit offences existed; this information was available to the superior; and the superior, while aware that such a category of information existed, declined to refer to the category of information. ${ }^{42}$

Thus, the threshold to be fulfilled for a civilian superior to be responsible is higher than the one required for military commanders.

\section{Fifth Element: The Superior's Failure to Prevent, Repress, or Punish the Crimes}

Under the fifth element, it must be proven that the superior failed to fulfil either one of the following three duties:

the duty to prevent crimes, the duty to repress the crimes, or the duty to submit the matter to the competent authorities for investigation and prosecution. ${ }^{43}$

In Bemba's case, the Trial Chamber noted that

the three duties under Article 28(a) of the Statute arise at three different stages in the commission of crimes: before, during and after. $^{44}$

The duty to prevent exists prior to the commission of the crime. Bemba's case provided several measures in light of the duty to prevent. This implies to ensure that the international humanitarian law (IHL), the laws and customs on the conduct of hostilities are well taught and disseminated to the subordinates, to collect reports that

\footnotetext{
40 Kai Ambos "Superior responsibility" in Rome Statute Commentary, 851; Vetter, 124.

41 Čelebići's case, para. 387.

42 Kai Ambos "Superior responsibility" in Rome Statute Commentary, 852.

43 Bemba's case, para. 435.

44 Ibid., para. 436.
} 
show that subordinates actions were in accordance with the IHL, to issue orders to bring actions in compliance with the IHL and to take disciplinary measures to prevent the commission of the crimes. ${ }^{45}$ Furthermore, if a crime is about to be committed, the superior is obligated to intervene by issuing orders against the subordinate. ${ }^{46}$

The duty to repress has two aspects. First is a duty to stop ongoing crimes from continuing and the second is a duty to punish subordinates after the commission of the crime. ${ }^{47}$ The Chamber is also of the view that either the superior himself can take action to punish the subordinate or refer the matter to competent authorities.

After the commission of the crime, the superior is obliged to submit the matter to competent authorities for investigation and prosecution. ${ }^{48}$

\section{Sixth Element: "the crimes concerned activities within the responsibility and control of the superior"}

The standard for civilian superior responsibility under Article 28(b) has an extra element that the subordinates' crimes must concern "activities that were within the effective responsibility and control of the superior." This element cannot be found in the military commander's responsibility under Article 28(a). One may raise the question regarding its purpose: why it is added to the civilian standard. Vetter argues that

civilian superiors do not have the same kind of around-the-clock, seven-day-a-week control over subordinates that military commanders have.

This is a potential explanation recognising the nature of civilian authority ${ }^{49}$ Nevertheless, at the end of the day, it will be for the ICC to construe the actual rationale behind this extra element.

\footnotetext{
45 Ibid., para. 438.

46 Kai Ambos "Superior responsibility" in Rome Statute Commentary, 844.

47 Bemba's case, para. 439.

48 Ibid, para. 442.

49 Greg R. Vetter, "Command Responsibility of Non-Military Superiors in the International CriminalCourt (ICC)," The Yale Journal of International Law, 25 (2000): 89-143, 120.
} 
The next section will discuss about the nature of constitutional monarchy, the position of constitutional monarchs as commanders-inchief, and their role in the actual structure of the executive. After that, the following section will apply the elements of superior responsibility to the situation of constitutional monarchs.

\section{CONSTITUTIONAL MONARCHS AS COMMANDERS-IN- CHIEF: THE PRACTICE OF SELECTED COUNTRIES}

There are two forms of monarchy that are greatly different from each other i.e., absolute monarchy and constitutional monarchy. Absolute monarchy is a governmental system where the monarch holds the supreme or absolute powers, as in a dictatorship. His absolute powers may not be questioned by anyone. He is indeed above the law. There is no legislative body nor any court that can challenge his absolute powers. In fact, whatever he utters is law for the people to comply with, without any question. ${ }^{50}$

The concept of the absolute monarchy declined substantially after the French Revolution, the Glorious Revolution of Britain, and the rise of liberal democracy in Europe. After World War I, most of the absolute monarchs were transformed into constitutional monarchs. ${ }^{51}$

What is the difference between the two types of monarchies? The primary difference is that whereas the power of the absolute monarch is unlimited, the power of a constitutional monarch is limited by the constitution. ${ }^{52} \mathrm{~A}$ constitutional monarch is as a rule a ceremonial ruler or a figurehead of the State..$^{53}$

50 Carsten Anckar, "Constitutional Monarchies and Semi-Constitutional Monarchies: aGlobal Historical Study, 1800-2017," Contemporary Politics, Routledge, Taylor \& Francis Group (2020): 1-17, at 2.

51 In the modern time, there are only seven States that practise absolute monarchy: Brunei, Eswatini, Oman, Qatar, Saudi Arabia, the individual emirates of the United Arab Emirates (UAE), and the Vatican City. List of Current Monarchies, Wikipedia, the Free Encyclopedia, accessed July 24, 2021, https://en.wikipedia.org/wiki/List_of_current_monarchies.

52 "What is the Difference between Absolute Monarchy and Constitutional Monarchy," PEDIAA, March 22, 2021, accessed August 16, 2021, 
In a constitutional monarchy, the monarch acts as the Head of State within the purview of a written or unwritten constitution. Constitutional monarchs primarily practise a parliamentary system in which the Monarch may have strictly ceremonial duties or certain reserve powers, depending on the constitution. ${ }^{54}$ There is an elected Prime Minister who is the head of government and exercises effective executive power. Though the monarch may be regarded as the government's symbolic head, it is the Prime Minister who actually governs the country. ${ }^{55}$

Bogdanor succinctly enunciates the nature of constitutional monarchy in the following manner:

In modern democracies, the monarch can perform only a very small number of public acts without the sanction of his ministers. The constitution does not allow the monarch to govern. A

https://pediaa.com/what-is-the-difference-between-absolute-monarchyand-constitutional-monarchy/.

53 The following thirty-two States practice constitutional monarchy: Andorra, Antigua \& Barbuda, Australia, The Bahamas, Bahrain, Barbados, Belgium, Belize, Cambodia, Canada, Denmark, Grenada, Jamaica, Japan, Malaysia, Lesotho, Luxembourg, The Netherlands, New Zealand, Norway, Papua New Guinea, Saint Kitts \& Nevis, Saint Lucia, Saint Vincent \& the Grenadines, Solomon Islands, Spain, Sweden, Thailand, Tonga, Tuvalu, and the United Kingdom.

54 Constitutional monarchies where the monarch has a largely ceremonial role may also be referred to as "Parliamentary Monarchies." See Rainer Grote, "Parliamentary Monarchy," Max Planck Encyclopedia of Comparative Constitutional Law, January 2016, 2.

55 Some commentators are of the view that there are certain monarchies whose monarch is not merely ceremonial but can exercise actual executive powers. They are known as "semi-constitutional monarchies." In semi-constitution monarchies, the monarch wields significant (though not absolute) power. The following states are semi-constitutional monarchies: Jordan, Kuwait, Liechtenstein, Monaco, and Morocco. See Carsten Anckar, "Constitutional Monarchies and Semi-Constitutional Monarchies: a Global Historical Study, 1800-2017," Contemporary Politics, Routledge, Taylor \& Francis Group (2020): 1-17. 
constitutional monarch, therefore, is a sovereign who reigns but does not rule. ${ }^{56}$

Bulmer agrees with Bogdanor and further elaborates on the benefits of having a constitutional monarchy in these terms:

A constitutional monarch in a parliamentary democracy is a hereditary symbolic head of state who does not exercise executive or policy making power. A constitutional monarch, with a ceremonial figurehead role, may provide continuity and stability, provide a unifying non-partisan representative of the state, and reinforce democratic legitimacy with other sources of authority, including traditional and in some cases religious authority. ${ }^{57}$

In most countries around the world, Heads of States are honoured with the position of commander-in-chief. There are generally two types of Heads of States. First, there are Heads of States with real executive powers, such as the President of the United States of America. ${ }^{58}$ Secondly, there are mostly ceremonial Heads of States, such as constitutional monarchs and presidents in parliamentary republics. ${ }^{59}$

56 Vernon Bogdanor, "The Monarchy and the Constitution," in Vernon Bodganor, The Monarchy and the Constitution (Oxford: Oxford University Press, 1995) 407-422, at 407.

57 Elliot Bulmer, Constitutional Monarchs in Parliamentary Democracies, International IDEA Constitution-Building Primer 7 (Stockholm: International Institute for Democracy and Electoral Assistance (International IDEA), 2nd. ed., 2017), 3.

58 Article II, Section 2, Clause 1 of the US Constitution states that "the President is the commander-in-chief of the American armed forces." "Maintaining a civilian status and without any military rank, the President exercises supreme operational command and control over military personnel, direct and supervise military operations, order or authorize the deployment of troops and unilaterally launch nuclear weapons." See generally, Joseph G. Dawson, ed., Commanders in Chief: Presidential Leadership in Modern Wars. (Lawrence, KS: University Press of Kansas, 1993).

59 India is an example of parliamentary or democratic republic. The president is the head of the State and the nominal head of the executive. According to Article 53(2) of the Indian Constitution, "the supreme command of the Defence Forces is vested in the President." However, the Cabinet headed by the Prime Minister has the effective executive 
The present article primarily focuses on the role of constitutional monarchs as the commanders-in-chief. Three constitutional monarchs - Britain, Japan, and Malaysia - are selected for the purpose of exploring whether monarchs in these countries, being the commanders-in-chief, could be held responsible under the doctrine of superior responsibility as enshrined in Article 28 of the Rome Statute.

\section{The British Practice}

Thomas Macaulay succinctly commented on the true nature of constitutional monarchy as practised in England:

According to the pure idea of constitutional royalty, the prince reigns, and does not govern; and constitutional royalty, as it now exists in England, comes nearer than in any other country to the pure idea. ${ }^{60}$

According to the British constitution, the head of the Armed Forces is Queen Elizabeth II to whom members of the armed forces swear allegiance. ${ }^{61}$ The interesting question here is: Does Her Majesty the Queen as the Commander-in-Chief has effective control over the British Armed Forces?

According to the constitutional convention, in the event of a situation of armed conflict or the deployment of the British armed forces to military action, the Prime Minister shall issue the authorisation. Decisions to initiate military actions are made within

power to control the Defence Forces and this is implemented through the Ministry of Defence headed by the Minister of Defence.

60 Thomas Macaulay, The History of England from the Accession of James the Second (1848), in five volumes, as quoted in Vernon Bogdanor, "The Monarchy and the Constitution,", at 407. See also Stephen Woods, "What is the Queen's Role in the British Government? Gone are the Days of Absolute Monarchy. Today the Queen's Duties are Merely Ceremonial." History News Letter, November 17, 2020, accessed August, 23, 2021, https://www.history.com/news/what-is-the-queensrole-in-british-government.

61 "Queen and the Armed Forces," accessed September 2, 2021, https://www.royal.uk/queen-and-armed-forces-0. 
the Cabinet with advice from, among others, the Chief of the Defence Staff. ${ }^{62}$

Like all other ministers, the Prime Minister appoints the Secretary of State for Defence, who is a member of the Cabinet and Chair of the Defence Council. The Cabinet, chaired by the Prime Minister, is the ultimate decision-making body of government and ministers are bound by the collective decisions of the Cabinet. ${ }^{63}$

The Defence Operating Model of the Government of the United Kingdom enunciates:

Ministry of Defence (MOD) is led by the Permanent Secretary, as the Secretary of State's principal policy adviser, and the Chief of the Defence Staff, as the professional head of the Armed Forces and principal military adviser to the Secretary of State. There are four commands under the MOD: the Royal Navy, the Army, the Royal Air force, and the Strategic Command. ${ }^{64}$

What is stated above is the chain of command in relation to the British armed forces. The highest executive authority is vested in the Prime Minister. The Secretary of State for Defence is the second in the chain of command, seconded by the Chief of the Defence Staff of the MOD, and followed by the commanders (or chiefs) of the four military commands. ${ }^{65}$

It can thus be concluded that, although Her Majesty the Queen has symbolic power over the British Armed Forces as the commander in chief, she does not in practice exercise any executive or operational power to order or command the armed forces. The main decisionmaking power over military operations and deployment of armed forces rests with the Prime Minister and the Ministry of Defence. On this basis, the Queen would lack effective control over the British

62 Gail Bartlett \& Michael Everett, The Royal Prerogative, Briefing Paper, Number 03861, 17 August 2017, House of Commons Library, 19-20. See also Claire Mills, Parliamentary approval for military action report, House of Commons Library, 8 May 2018.

63 Government of the United Kingdom, "How Defence Works: the defence operating model," version 6.0, September 23, 2020, accessed August 12, 2021,https://www.gov.uk/government/publications/how-defence-worksthe-defence-operating-model.

64 Ibid.

65 Ibid. 
Armed Forces and would not be responsible for the crimes committed by the armed forces under the doctrine of superior responsibility.

\section{The Position of Emperor Hirohito during World War II and the Present Japanese Emperor}

Emperor Hirohito of Japan was the commander-in-chief during World War II and was not tried or indicted in the Tokyo trial. This has created a hot debate among lawyers and politicians alike. The views of commentators are divided. The first point of view is that at the time of World War II, Hirohito was merely a constitutional monarch, he had no effective control over the armed forces, and therefore he would not be responsible for the crimes committed by these armed forces. ${ }^{66}$ It is submitted that this is not the case.

First, let us look at the Constitution of the Empire of Japan also known as the Meiji Constitution, 1889. The Emperor was described as sacred and inviolable. ${ }^{67} \mathrm{He}$ was not only the Head of the Empire but "sovereignty vests in him." 68 The Emperor exercises the legislative power though with the consent of the Imperial Diet. ${ }^{69}$ "The Emperor gives sanction to laws and orders them to be promulgated and executed." ${ }^{\prime 70}$ The Emperor appoints and dismisses different branches of the administration and all civil and military officers. ${ }^{71}$ The Emperor is the supreme commander of the armed forces. ${ }^{72}$ The Emperor declares war, makes peace and concludes treaties. ${ }^{73}$

To be a constitutional monarchy, the monarch must have surrendered most of his sovereign powers and handed over these powers to an elective legislature and a cabinet headed by a Prime Minister who can exercise effective executive powers. Although there

66 See, for example, Fauziah Mohd Taib, "All is not Lost Despite Rome Statute Withdrawal," New Straits Times, Opinion, May 12, 2019.

67 Article 3, The Constitution of the Empire of Japan 1889, translated by Ito Miyoji; accessed August 19, 2021, https://www.ndl.go.jp/constitution/e/etc/c02.html.

68 Article 4, ibid.

69 Article 5, ibid.

70 Article 6, ibid.

71 Article 10, ibid.

72 Article 11, ibid.

73 Article 12, ibid. 
is an elected Imperial Diet i.e., a hint of a democratic idea, nowhere in the Meiji constitution can one find any provision about the elected Prime Minister and cabinet with actual executive powers. It appears that the Prime Minister, ministers, and other civil and military officials could be appointed and dismissed by the Emperor. The constitution did not provide that the Emperor must act on the advice of the Prime Minister.

It is therefore crystal clear that the Meiji Constitution was not based on constitutional monarchy. Although there is a slight flavour of a democratic idea, the idea of absolute monarchy is more apparent. ${ }^{74}$ Sharifah Munirah thus observes:

While in theory, the Meiji constitution contained underpinnings of democracy, in practice it created an absolute monarchy with all power emanating from the Emperor. He played a central role in the governance of Japan, had absolute executive power and a supreme 'god-like' aura. ${ }^{75}$

Some commentators do not dispute the absolute monarchy trend of the Meiji constitution, but they argued that in practice Hirohito acted as a constitutional monarch and he had no ability or willingness to oppose or control the decisions of the military. ${ }^{76}$

By referring to Hirohito's own monologue, Noriko wrote that with regard to decision making in wartime, the Imperial Conference set up by Prime Minister Konoe in 1937 was a proof that Emperor Hirohito had no actual powers and rather his position was symbolic in nature. ${ }^{77}$ Noriko cited numerous statements made by Hirohito himself and other Japanese officials after the war to the effect that Hirohito actually wanted peace and not war and he was powerless under the

74 At best, it can be executive monarchy or semi-constitutional monarchy.

75 Sharifah Munirah Alatas, "Some errors in historical analysis" New Straits Times, May 15 2019, accessed August 17, 2021, https://www.nst.com.my/opinion/letters/2019/05/488755/some-errorshistorical-analysis.

76 Saki Dockrill, "Hirohito, the Emperor's Army and Pearl Harbor" Review of International Studies 18, no. 4 (1992): 321.

77 Ibid., 324; Noriko Kawamura, "Emperor Hirohito and Japan's Decision to Go to War with the United States Reexamined" Diplomatic History 31, no. 1 (2007): 58. 
pressure of army generals to finally accept war and concluded that Hirohito was blameless. ${ }^{78}$

On the other hand, the American historian Herbert Bix portrayed the emperor as a war-like man, involved in political and military decisions, strongly supportive of the army, and resistant to ending the war in early 1945 . He argued that he bore responsibility for failing to exercise the leadership needed to end the war. ${ }^{79}$

Whether Hirohito was a constitutional monarch or an absolute monarch during World War II is rather a legal as well as a factual question. However, it seems that politics was the main reason behind the question of why Hirohito was not indicted and tried: internal politics as well as US politics. Internal factors include the Japanese national psyche to protect their throne (representing the State) and its owner, revered by most of them. External factors include the policy of the Truman Administration not to destroy the Japanese monarchy system, to retain Hirohito intact for, national unity, smooth and successful implementation of reforms and rebuild of the war-torn country. General MacArthur was responsible for implementing this policy and he worked hard to shield Hirohito from the trial. ${ }^{80}$

It is important to determine the position of the Japanese Emperor under the present constitution. The Constitution of Japan, 1946, provides in Article 1 that

The Emperor shall be the symbol of the State and of the unity of the People, deriving his position from the will of the people with whom resides sovereign power. ${ }^{81}$

78 Noriko, 61, 65, 70 .

79 Herbert P. Bix, Hirohito and the Making of Modern Japan (Harper Collins Perennial Edition, 2001) 585-6. Herbert Bix won the Pulitzer Prize for this book. However, Kenneth was of the view that "a good many historians found Bix's view of the emperor as war-like man overdrawn." See Kenneth B. Pyle, "Hiroshima and the Historians: History as Relative Truth," The Pacific Northwest Quarterly, 104: 3 (Summer 2013): 123-132, at 129.

80 Herbert P. Bix, "War Responsibility and Historical Memory: Hirohito's Apparition," The Asia Pacific Journal: Japan Focus, 6:5 (2008): 1-18, at 7-11.

81 Article 1, the Constitution of Japan, promulgated on November 3, 1946, entered into force on May 3, 1947, accessed September 12, 2021, 
The constitution stresses that the emperor has no powers related to governance. ${ }^{82}$ In relation to the traditional functions of the Head of State, the Emperor has to act with the advice and approval of the Cabinet. ${ }^{83}$ The executive power is entirely vested in the Cabinet led by the Prime Minister. ${ }^{84}$

By virtue of the above constitutional provisions, Japan can be considered a constitutional monarchy in the strict sense of the term. The Japanese Emperor thus will not be responsible for any wrongful act committed by the government or the military under the doctrine of superior responsibility.

\section{The Malaysian Practice and the YDPA}

In Malaysia, the Yang di-Pertuan Agong (YDPA) is a constitutional monarch like the Queen in the United Kingdom. Sultan Azlan Shah observes:

The British introduced to Malaya their system of Government and their principles of constitutional law... the Merdeka Constitution became a masterpiece of compromise. ${ }^{85}$

This position is deeply rooted in the drafting history of the constitution. In relation to the position of the Yang di-Pertuan Agong, Jennings observed that he would not exercise the discretionary powers of the High Commissioner but would act on the advice of the government of the federation. ${ }^{86}$ The Reid Commission felt the rulers should not be involved in politics or be given many political functions

https://japan.kantei.go.jp/constitution_and_government_of_japan/constit ution_e.html.

82 Article 4, ibid.

83 Article 7, ibid.

84 Articles 65-66, ibid.

85 Sultan Azlan Shah, "The Role of Constitutional Rulers," in VisuSinnadurai (ed.) Constitutional Monarchy, Rule of Law, and Good Governance: Selected Essays and Speeches of Sultan Azlan Shah, (Thomson, Sweet \& Maxwell Asia, 2004) 251-288, at 255-56.

86 Paper by Sir Ivor Jennings titled, "Constitutional Changes Implicit in the Terms of Reference." 23 Aug. 1956, p. 2, CO 889/2, C.C. 2000/15, as cited in Joseph M. Fernando, "Defending the Monarchy: The Malay Rulers and the Making of the Malayan Constitution, 1956-1957,' Achiepel 88, (2014): 149-167, at 153. 
or powers in keeping with the general understanding of the concept of constitutional monarchy based on the British model. ${ }^{87}$ This is the origin of the basic principle that the YDPA has to act in accordance with the advice of the cabinet. ${ }^{88}$

One of the main characteristics of Malaysia's Federal Constitution is that there is a system of the constitutional monarchy at both the state and federal levels. ${ }^{89}$ Article 32 of the Federal Constitution provides that the YDPA is the Supreme Head of the Federation. ${ }^{90} \mathrm{He}$ is also the Supreme Commander of the Armed Forces pursuant to Article 41 of the Federal Constitution. ${ }^{91}$

One commentator argued that the YDPA's role as the Supreme Commander of the Armed Forces is not merely symbolic or ceremonial, by relying on an obiter dictum of a dissenting opinion in the case of Armed Forces Council, Malaysia \& Anor v Major Fadzil bin Arshad. ${ }^{92}$ In that case, Mohd Hishamudin JCA stated in his dissenting opinion:

As the Supreme Commander of the armed forces, His Majesty's role could not have been intended by the framers of our Constitution to be merely symbolic or just a figurehead. Surely His Majesty is expected to play an effective and meaningful role as the Supreme Commander. ${ }^{93}$

The commentator nevertheless did not admit first that it was merely an obiter dictum and not a ratio decidendi and secondly that it was

87 See Summary record of 33rd meeting of constitutional commission, 17 Sept. 1956, pp. 1-2, CO 889/1 (36). See also Summary record of 34th meeting of constitutional commission, 26 Sept. 1956, pp. 1-2, CO 889/1 (37), ibid.

88 The exceptional cases where the YDPA can exercise the discretionary power are enumerated in Article 40(2).

89 Shad Saleem Faruqi, Our Constitution (Subang Jaya: Thomson Reuters Asia Sdn Bhd, 2019), 40. See also Report of the Federation of Malaysia Constitutional Commission, 1957, London: Colonial No. 330, HMSO.

90 Federal Constitution of Malaysia, Article 32.

91 Ibid, Article 41.

92 Fareed Mohd Hassan, "Malaysia's ICC Membership Too Hasty?" Asia Sentinel, March 12 2019, accessed September 15, 2021. https://www.asiasentinel.com/p/malaysia-international-criminal-courtmembership-too-hasty.

93 [2012] 1 MLJ 313, Court of Appeal, para. 38. 
merely a dissenting opinion of a judge, not the ruling of the Court of Appeal, and thus this is in no way authoritative. ${ }^{94}$

Furthermore, the commentator appears to have failed to recognise the paramount provision of the constitution, that is, "to act on advice," which clearly demonstrates the fact that YDPA is not an absolute monarch but merely a constitutional monarch. Article 40(1) of the Federal Constitution enshrines that:

In the exercise of his functions under this Constitution or federal law, the YDPA shall act in accordance with the advice of the Cabinet or a Minister acting under the general authority of the Cabinet. ${ }^{95}$

To strengthen the concept of constitutional monarchy and to further clarify the meaning of "to act on advice," a new clause, Article 40(1A), was added by an amendment Act in 1994, which provides that

In the exercise of his functions under this Constitution or federal law, where the YDPA is to act in accordance with advice, on advice, or after considering advice, the YDPA shall accept and act in accordance with such advice. ${ }^{96}$

Shad Saleem Faruqi maintains that most of the powers of the YDPA are non-discretionary in nature and this includes his performance of the functions of the Supreme Commander of the Armed Forces. ${ }^{97} \mathrm{He}$ further stresses that these powers and functions are in practice vested in the Prime Minister. This is because Article 39 of the Federal Constitution makes it clear that there is a distinction between the

94 Lim Wei Jiet, "A Rebuttal of the Alleged Academic Presentation to Rulers," Malaysiakini, 8 April 2019, accessed September 13, 2021, https://www.malaysiakini.com/news/471305.

95 Federal Constitution of Malaysia, Article 40(1).

96 Ibid., Article 40(1A), as amended by the Constitution Amendment Act 1994 (Act A885), which Entered into force on 24 June 1994 [Emphasis added].

97 Shad Saleem Faruqi, Document of Destiny: The Constitution of the Federation of Malaysia (Petaling Jaya: Star Publications (Malaysia) Berhad, 2008), 438. 
person (YDPA) in whom executive authority is vested and the person or persons by whom it is exercisable. ${ }^{98}$

Therefore, the argument that the YDPA's role as the Supreme Commander of the Armed Forces is not merely symbolic holds no water. The YDPA's role as the Supreme Commander is indeed symbolic and ceremonial in nature.

\section{The Military Chain of Command}

To deal with matters relating to the armed forces on behalf of the YDPA, the Federal Constitution establishes a body known as the Armed Forces Council. Article 137(1) of the Federal Constitution provides:

There shall be an Armed Forces Council, which shall be responsible under the general authority of the YDPA for the command, discipline and administration of, and all other matters relating to, the armed forces, other than matters relating to their operational use..$^{99}$

The defence minister chairs the Armed Forces Council. However, matters relating to the operational use of the Malaysian Armed Forces (MAF) remain the authority of the National Security Council (NSC), chaired by the Prime Minister. ${ }^{100}$

Considering Article 137(1), it is clear that the YDPA does not have any authority over the operational use of the armed forces. While the YDPA may be involved with the administration of the armed forces, such as issuing commission credentials of commissioning of military

98 Ibid. Article 39 of the Federal Constitution provides that "The executive authority of the Federation shall be vested in the Yang di-Pertuan Agong and exercisable... by him or by the Cabinet or any Minister authorised by the Cabinet..." [Emphasis added].

99 Article 137(1), Federal Constitution of Malaysia [Emphasis added].

100 Malaysia Ministry of Defence, Online data, accessed September 16, 2021, https://www.globalsecurity.org/military/world/malaysia/mod.htm. The National Security Council (NSC) has been established under the National Security Council Act 2016. 
officer on the recommendation of the Armed Forces Council, ${ }^{101}$ the YDPA does not give orders on military operations. ${ }^{102}$

The following is the official organisational structure of the Ministry of Defence:

The Ministry is led by the Minister of Defence and assisted by a deputy minister. The organisation of the Ministry of Defence consists of two main services. Public Service is headed by the Secretary General and the Malaysian Armed Forces (MAF) is headed by the Chief of the Armed Forces. ${ }^{103}$

The Chief of the Armed Forces Staff Committee (Jawatankuasa Panglima-Panglima) (JPP) is entrusted with joint planning and coordination of the armed forces. The JPP is also responsible to give the Ministry of Defence and the National Security Council (NSC) professional advice on strategy and operations. The JPP is chaired by the Chief of the Armed Forces, and included as members are: Chief of Army, Chief of Navy, Chief of Air Force, the Commander of Joint Force, the Director of General Defence Intelligence, and the Chief of Staff of the Ministry of Defence. ${ }^{104}$ Based on the organisational structure of the Malaysian Armed Forces, the chain of command in military operations does not reach the YDPA. ${ }^{105}$

As far as the operations of the armed forces are concerned, the chain of command starts from the lower levels of unit/brigade/division commanders to the chief of army/navy/air force, etc. and then goes up to the Chief of the Armed Forces Staff Committee (Jawatankuasa Panglima-Panglima (JPP)), chaired by the Chief of the Armed Forces. ${ }^{106}$ However, administratively, they are under the control of the higher civilian authority, the Minister of

101 Armed Forces Act 1972, Section 6 (1).

102 Mohammad Suffian Hashim, "The Role of Monarchy", Insaf, Jil. 20 Bil. 3, (September 1987) 24.

103 Ministry of Defence, Malaysia (MINDEF) Official Website, accessed September 16, 2021, https://www.mod.gov.my/en/about-us/background. [Emphasis added].

104 Malaysia Ministry of Defence, Online data, accessed September 16, 2021, https://www.globalsecurity.org/military/world/malaysia/mod.htm.

105 Ahmad Atory Hussain, Pengantar Pentadbiran Awam Paradigma Baru. (Kuala Lumpur: Utusan Publications and Distributors Sdn. Bhd.2004).

106 Malaysia Ministry of Defence, Online data, accessed September 16, 2021, https://www.globalsecurity.org/military/world/malaysia/mod.htm. 
Defence, who sits in both the NSC and the Cabinet and of course the highest administrative authority is held by the Prime Minister, the Head of Government.

Since Malaysia is peaceful, not involved in any war or aggression and there are no armed conflicts within or outside the country these days, there can be no concrete precedents to show the practical implementation of the above military chain of command. However, there were two recent cases of the deployment of armed forces, the first one relates to peace-keeping forces and the other one is in relation to the enforcement of COVID 19 SOPs.

The then Minister of Defence Mohammad Sabu announced on 3 October 2019 that the Malaysian Battalion 850-7 (Malbatt 850-7), comprising of 216 members of the Malaysian Armed Forces (MAF) would be deployed to Lebanon to serve under the United Nations Interim Force in Lebanon (UNIFIL) peacekeeping mission. It appears that it was arranged by the Minister of Defence, of course with the approval given by the Prime Minister in the Cabinet or in the NSC. ${ }^{107}$ Again on 3 March 2020, the then Minister of Defence Ismail Sabri Yaakob declared that the Malaysian armed forces would be deployed to assist in enforcing stay-at-home orders and compliance with SOPs. ${ }^{108}$ This of course would also be in accord with the decision of the Cabinet and the NSC. In none of these incidents, the decisionmaking involvement of the YDPA could be seen.

To conclude, although the YDPA is stated in the constitution as the Supreme Commander of the Armed Forces, this position is ceremonial in nature because he is merely a constitutional monarch and according to Article 40(1) of the constitution, he must act only on the advice of the Prime Minister. By virtue of Article 137(1), he is not to involve in the operations of the armed forces. Since the YDPA is not in a position to have effective control over the armed forces, the

107 "First Batch Malbatt Leaves for Lebanon," Daily Express, 2 October 2019, accessed September 16, 2021 http://www.dailyexpress.com.my/news/141234/first-batch-malbattleaves-for-lebanon/.

108 "Malaysia to Deploy Army to Assist Coronavirus Measures," Anadolu Agency, 20 March 2020, accessed September 16, 2021,https://www.aa.com.tr/en/asia-pacific/malaysia-to-deploy-army-toassist-coronavirus-measures/1772982\#. 
military and civilian personnel, he would not be held responsible under Article 28 of the Rome Statute.

\section{CONSTITUTIONAL MONARCHS AND RESPONSIBILITY FOR THE INTERNATIONAL CRIMES COMMITTED BY SUBORDINATES}

Article 28 of the Rome Statute enunciates two forms of superior responsibilities i.e., the responsibility of military commanders and responsibility of civilian superiors. Since a constitutional monarch is not a military commander, he or she will fall under the civilian superior category. Whether he is responsible or not depends on whether his act fulfils the elements of Article 28(b).

The first element is simply the superior-subordinate relationship and there is no doubt that a constitutional monarch is a civilian superior. Of the remaining five elements, the most important one for a constitutional monarch to be fulfilled is whether the subordinates are under his "effective authority and control." In Bemba's case, the ICC ruled that "effective control" means the material ability or power to prevent and punish the commission of the crimes. The factors to be considered include:

His power to issue or give orders and the capacity to ensure compliance with the orders issued, the capacity to order forces under his command to engage in hostilities, and the authority to send forces where hostilities take place and withdraw them at any given moment.

Based on the analysis in the previous section, it is axiomatic that the position of the constitutional monarchs are ceremonial in nature though stated in their constitutions as the commanders in chief. They do not possess effective authority and control over military or civilian personnel down the hierarchy. Indeed, such authority and control is vested in the Prime Minister as the head of the executive, the minister of defence and the chief of the armed forces and the commanders who make the decisions on the deployment of the armed forces and military operations. The second and the most important element, therefore, is not fulfilled. It can fairly be concluded that the 
constitutional monarch will not be responsible for the international crimes committed by his subordinates. ${ }^{109}$

\section{CONCLUSION}

Article 28 of the Rome Statute plays an important role in international criminal law as it is an important tool to keep superiors accountable. It ensures that superiors, whether military or civilian, are diligent in their activities by ensuring liability from any omission. While some States have refused to become a party to the Rome Statute on the ground that it will expose their monarchs to a risk of prosecution before the ICC, the analysis in the earlier section of this paper has shown that constitutional monarchs, as the Commanders-in-Chief, do not have effective control over their armed forces to make them responsible under Article 28 of the Rome Statute. Therefore, such fears and justifications are unfounded. Rather, the accession to the Rome Statute would be for the benefit of humanity as a whole and should be seen as a strategic means to end impunity for perpetrators of crimes of concern to the international community.

109 It is enough to prove that one element is lacking and there will not be any responsibility. Still, there are four more elements that need to be fulfilled: causation, mens rea, failure to prevent or punish, and the fact that the crimes concerned activities that fall within the responsibility and control of the superior. 